\title{
Degeneratív és onkológiai indikációk alapján beültetett reverz vállprotézisek funkcionális kimenetelének összehasonlítása
}

\author{
Szatmári Attila dr. ${ }^{1}$ - Benedek Balázs dr. ${ }^{2}$ - Perlaky Tamás dr. ${ }^{1}$ \\ Szalay Krisztián dr. ${ }^{1}$ - Sallai Imre dr. ${ }^{1}$ - Skaliczki Gábor dr. ${ }^{1}$ \\ Szendrői Miklós dr. ${ }^{1}$ - Antal Imre dr. ${ }^{1}$
}

${ }^{1}$ Semmelweis Egyetem, Általános Orvostudományi Kar, Ortopédiai Klinika, Budapest
${ }^{2}$ Péterfy Sándor Utcai Kórház-Rendelőintézet és Baleseti Központ, Budapest

\begin{abstract}
Bevezetés: A válltáji primer és áttéti csonttumorok miatt végzett humerus proximalis vég reszekciókat követő rekonstrukcióra több módszer (csontgraft, endoprotézisek) is használatos. Az új eljárások egyike az ízületi felszínek és az eltávolított, különböző hosszúságú humerus proximalis vég reverz vállprotézissel, adott esetben csontbeültetéssel kiegészített (kompozit eljárás) pótlása, az elérhető jobb vállfunkció reményében.

Célkitüzés: A fenti eljárással általunk operált betegcsoport vállfunkciójának összevetése azon betegekkel, akiknél a reverz protézis indikációját degeneratív vállbetegség (rotátorköpeny-arthropathia) képezte. Továbbá annak vizsgálata, hogy a két csoport között mekkora különbséget találunk a vállfunkciót, stabilitást, a protézis megbízhatóságát illetően, azokat nem onkológiai jellegú értékelőrendszerekkel vizsgálva.

Módszer: A vizsgálatban 23 beteg vett részt (13 férfi, 10 nő), akiket 2012 és 2016 között operáltunk intézményünkben. Közülük 15-nél rotátorköpeny-arthropathia volt a reverz protézis indikációja, míg 8 esetben tumoros elváltozás miatt végeztük a humerus vállközeli reszekcióját, illetve a protetizálást. Betegeink átlagéletkora 62,5 év volt (17-82), az átlagos utánkövetés időtartama pedig 23,5 hónap (5-57). Betegeinknél fizikális vizsgálatot végeztünk, az operált karjukról röntgenfelvételek készültek, valamint funkcionális pontrendszerek alapján rögzítettük és elemeztük az adatokat.

Eredmények: A betegek által jelzett posztoperatív fájdalom mértéke csaknem megegyezett a két csoportban, azonban csak a rotátorköpeny-arthropathiás csoportban voltak olyan betegek, akik gyógyszeres fájdalomcsillapításra szorultak. Várakozásunkkal összhangban tumoros betegeink esetén mindhárom pontrendszerben valamelyest alacsonyabb értékeket kaptunk. A tumoros betegek az elért eredménnyel elégedettek voltak.

Következtetések: A humerus proximalis vég reszekciókat követôen a reverzprotézis-beültetés esetenként csontallografttal kiegészítve a rekonstrukció megbízható módszere, mely az elérhető funkciókat és a megbízhatóságot illetően megközelíti a nem tumoros indikációval vállprotetizált betegeknél tapasztalhatókat.

Orv Hetil. 2018; 159(45): 1838-1843.
\end{abstract}

Kulcsszavak: reverz vállprotézis, proximalis humerus reszekció, csontallograft

\section{Comparative functional outcome of reverse shoulder prostheses implanted on degenerative and oncological indications}

Introduction: Several methods (bone graft, endoprosthesis) are used to reconstruct proximal humerus resections due to primary and metastatic tumours. One of the new procedures is the replacement of the joint surfaces and the removed proximal humerus end with reverse shoulder prosthesis, optionally supplemented with bone implantation (composite procedure) in the hope of achieving better shoulder function.

Aim: The aim of this study was to compare the shoulder function of the patient group operated by the above procedure with reverse prosthesis to a patient group operated by indication of degenerative shoulder disease (rotator cuff arthropathy).

Method: The study involved 23 patients (13 men, 10 women) who were operated between 2012 and 2016 in our institution. Among them, 15 had rotator cuff arthropathy indication of reverse prosthesis, while in 8 cases, resection 
of the humerus and prosthesis implantation were performed due to tumour lesions. The average age of our patients was 62.5 years (17-82) and the average follow-up was 23.5 months (5-57). We performed physical examination, $\mathrm{X}$-ray pictures on their operated arm, and data were recorded and analysed based on functional score systems.

Results: The level of postoperative pain was almost the same in the two groups, but only the rotator cuff arthropathy group needed pain medications. In line with our expectations, we received slightly lower values by each of the three scoring systems in case of tumorous patients. The tumorous patients were satisfied with the results achieved.

Conclusions: Following proximal humerus resections, reversed prosthesis implantation with occasional bone allografts is a reliable method of reconstruction, which approaches available functions and reliability as compared to non-tumour-indicating patients.

Keywords: reverse shoulder prosthesis, proximal humerus resection, bone allograft

Szatmári A, Benedek B, Perlaky T, Szalay K, Sallai I, Skaliczki G, Szendrői M, Antal I. [Comparative functional outcome of reverse shoulder prostheses implanted on degenerative and oncological indications]. Orv Hetil. 2018; 159(45): 1838-1843.

(Beérkezett: 2018. június 12.; elfogadva: 2018. július 7.)

\begin{abstract}
Rövidítések
ASES $=$ American Shoulder and Elbow Surgeons Shoulder Score; DASH-Score $=$ Disabilities of the Arm, Shoulder and Hand Score; MSTS = Musculoskeletal Tumor Society; NSAID $=($ nonsteroidal antiinflammatory drug $)$ nemszteroid gyulladáscsökkentő gyógyszer; ROK = rotátorköpeny; SF-36 = Short Form (36) Health Survey; SSS = Subjective Shoulder Score
\end{abstract}

Napjainkban az ortopéd sebészet legtöbbet és legsikeresebben végzett beavatkozásait a nagyízületi endoprotetika képviseli. Az arthroplasticák közül térd- és csípőprotézis-beültetésekre kerül sor a legtöbbször (térd: 600 000/ év, Amerikai Egyesült Államok [USA]; csípő: 300 000/ év, USA) [1]. A harmadik leggyakrabban protetizált ízület a vállízület, melyek szintén jelentős számban végzett mútétek (66 000/év, USA, 33\% reverz vállprotézis) [2]. A reverzvállprotézis-rendszereket több indikáció alapján is sikeresen használhatjuk. A leggyakrabban degeneratív vállbetegségek (rotátorköpeny [ROK]-arthropathia) esetén alkalmazzuk, azonban a humerus proximalis vég darabos törése, autoimmun betegségek okozta súlyos arthritis, krónikus glenohumeralis diszlokáció vagy csonttumorok miatti humerus proximalis vég reszekciót követő rekonstrukció esetén is végezhetünk reverzvállprotézis-implantációt [3].

Olyan esetekben, amikor egy tumor eltávolítása során a humerus proximalis vég reszekciójára kerül sor, számos mútéti megoldás áll rendelkezésünkre, egyértelmú szakmai konszenzus azonban nincs az optimális rekonstrukciós eljárást illetően. A reverz vállprotézis-allograft kompoziton kívül másfajta rekonstrukciós lehetőségek is adottak, mint például az autológ fibulatranszplantáció, az osteochondralis allograft vagy a modulrendszerú anatómiai tumorendoprotézis (hemiarthroplastica) $[4,5]$. Ezen utóbbi eljárások sikeresnek tekinthetők abból a szempontból, hogy a könyök- és a csuklófunkció akár teljes mértékben megtartott maradhat. Továbbá ha a szokásos tumoros pontrendszerek alapján vizsgálták őket
(MSTS, DASH-Score, SF-36) [6], akkor a klinikai vizsgálatok során még a gyengébb vállfunkció és szúk aktív mozgástartomány ellenére is jól teljesítettek [5, 7]. Egy tumor miatt végzett humerus proximalis vég reszekció alkalmával a rotátorköpenyinak is eltávolításra kerülnek a humerusfejjel együtt, azaz éppúgy hiányoznak, mint egy rotátorköpeny-arthropathia miatt végzett vállprotézisbeültetéskor. Ennek alapján merült fel az az elgondolás, hogy a rotátorköpeny-arthropathiánál bevált reverz vállprotézist a tumorreszekcióknál is alkalmazzák [8].

\section{Célkitüzés}

Vizsgálatunk célja az volt, hogy utánkövessük és felmérjük a klinikánkon ROK-arthropathia és humerus proximalis vég reszekció miatt reverz vállprotézissel ellátott betegeinket, majd a pontrendszerek segítségével (Constant Shoulder Score, ASES, Subjective Shoulder Score) összehasonlítsuk a két különböző indikációval beültetett protézisek funkcióját.

\section{Módszer}

Retrospektív vizsgálatunkba 23 beteget vontunk be ( 13 férfi, 10 nő), akiket 2012 és 2016 között operáltunk a Semmelweis Egyetem Ortopédiai Klinikáján. 15 esetben rotátorköpeny-arthropathia miatt ültettünk be reverz vállprotézist, míg 8 esetben tumoros elváltozás miatti humerus proximalis vég reszekció rekonstrukcióját végeztük reverz vállprotézis-allograft kompozit segítségével. A szövettani diagnózis 3 betegnél chondrosarcoma, 3 betegnél hypernephroma csontmetasztázisa, egy esetben osteosarcoma és egy esetben Ewing-sarcoma volt. A betegek átlagos életkora 62,5 év volt (17-82), az átlagos utánkövetési idő pedig 23,5 hónap $(5-57)$.

Betegeink követése során minden esetben történt fizikális vizsgálat, röntgenfelvétel az operált oldalról, valamint Constant, ASES és Subjective Shoulder Score funk- 


\section{$\square$ Constant Score $\square$ ASES Score $\square$ Subjective Shoulder Score}

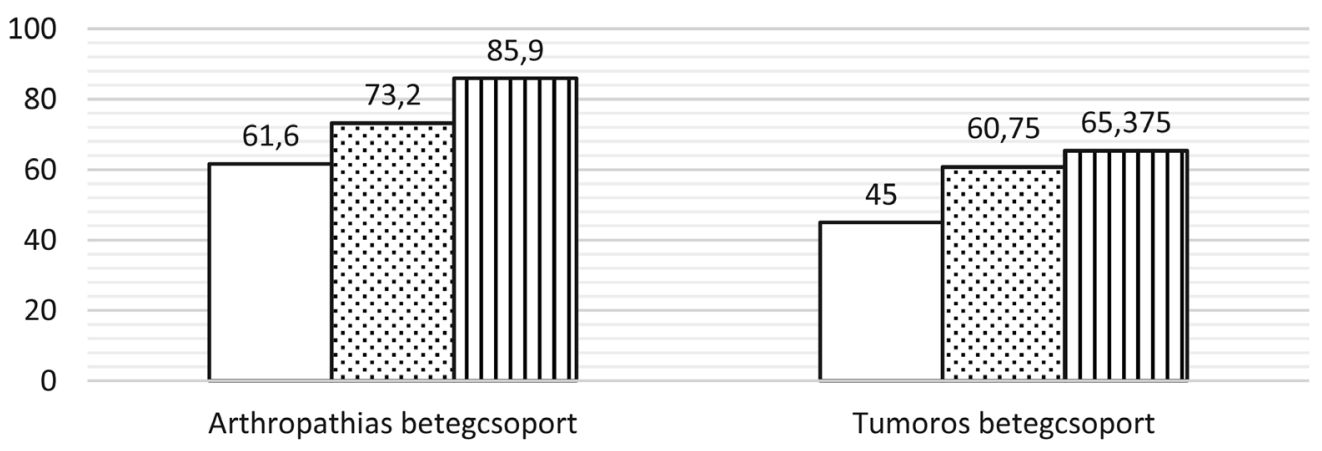

1. ábra A két csoport átlagos funkcionális pontértékei

cionális pontszámítás. Mind a három pontrendszer figyelembe veszi mind a beteg végtag funkcionalitását, mind a betegek esetleges szubjektív fájdalomérzetét, valamint hogy milyen mértékben befolyásolja a mütét a mindennapi életüket. A röntgenfelvételeken a protézis körüli esetleges osteolysist, továbbá a tumoros betegeknél a beültetett allograft átépülését is elemeztük.

\section{Eredmények}

A tumoros betegcsoport esetén az átlagos életkor 49,75 év (19-66), az átlagos utánkövetési idő 29,5 hónap (552 ) volt. A ROK-arthropathia jellemzően időskori degeneratív betegség lévén, az átlagos életkor szignifikánsan magasabb volt: 70,8 év (59-82). Az utánkövetési idő a másik csoporthoz hasonlóan átlagosan 20,5 hónap (757) volt.

$\mathrm{Az}$ 1. ábrán a két csoport betegeinek funkcionális pontrendszerek alapján mért átlagértékei szerepelnek. A tumoros csoportban a Constant átlaga 45, az ASES átlaga 60,75 , az SSS átlaga 65,375 volt. Látható, hogy a ROK-arthropathiás csoportban a betegek átlagos pont- értékei magasabbak. A Constant átlaga 61,6, az ASES átlaga 73,2, míg az SSS átlaga 85,9 volt.

Vizuális analóg skála segítségével felmértük a betegek mütét utáni fájdalomszintjét is. Ahogyan az a 2. ábrán is látható, a fájdalmat illetően nincs különbség a két csoport betegei között. Mindkét csoportban a betegek 75$80 \%$-a fájdalommentes, vagy csak enyhe fájdalmuk volt. Egyik betegnek sem volt akár állandó, akár éjszakai fájdalma, a legtöbbször csak bizonyos mozdulatokra jeleztek fájdalmat. A ROK-arthropathiás csoport betegei közül hárman szedtek rendszeresen valamilyen fájdalomcsillapítót, ketten NSAID-készítményt, míg egy beteg opioid analgetikumot (Tramadol). A daganatos betegcsoport tagjai közül senki sem igényelte fájdalomcsillapítók rendszeres szedését.

Fizikális vizsgálataink alkalmával lemértük a betegek operált vállának mozgástartományát. A vártnak megfelelően a daganatos csoport betegeinek mozgástartománya valamelyest elmarad a másik csoport eredményeitől. A tumoros betegek átlagosan mind az anteflexio, mind az abductio terén $30^{\circ}$-kal maradnak el az arthropathiás betegektôl (3. ábra).
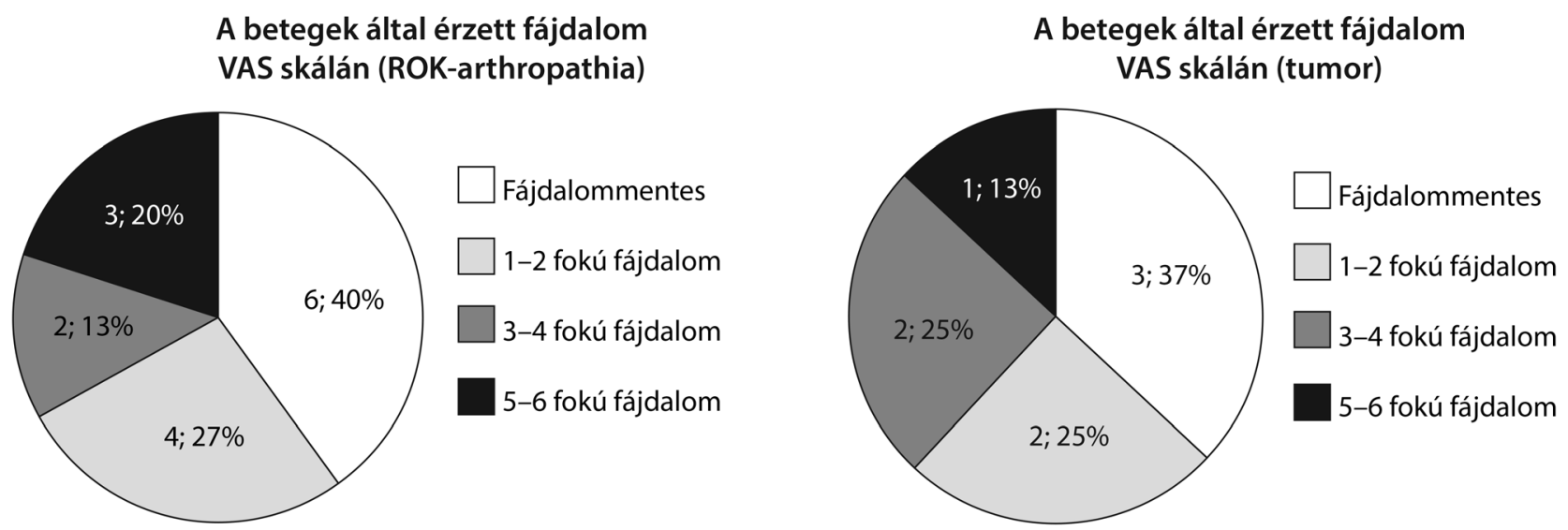

\begin{tabular}{l|l} 
2. ábra & $\begin{array}{l}\text { A két csoport összehasonlítása a fájdalom tekintetében vizuális analóg skála (VAS) használatával } \\
\text { ROK }=\text { rotátorköpeny }\end{array}$
\end{tabular} 


\section{Anteflexiós és abductiós mozgástartományok a ROK-arthropathiás csoportban}

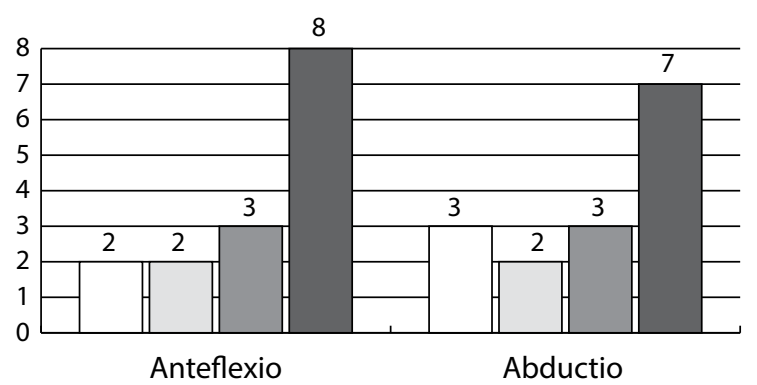

$\begin{array}{ll}\square \text { 61-90 fok } & \square \text { 91-120 fok } \\ \square \text { 121-150 fok } & \square \text { 151-180 fok }\end{array}$

\section{Anteflexiós és abductiós mozgástartományok a tumoros csoportban}
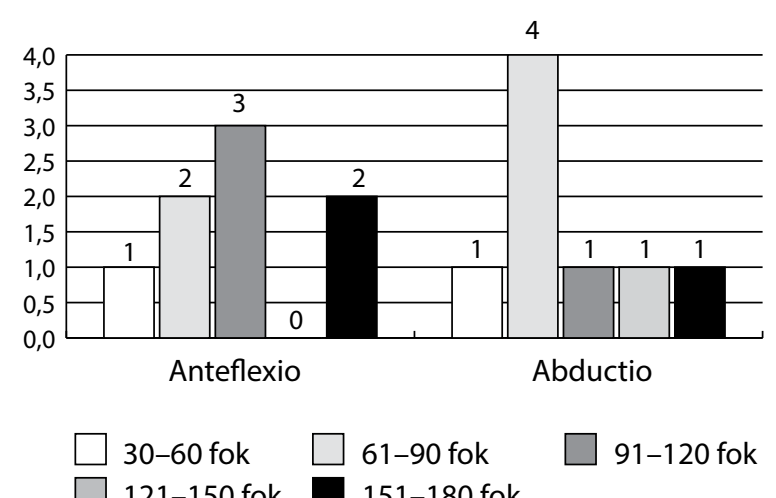

3. ábra

A két csoport anteflexiós és abductiós mozgástartományának összehasonlítása
ROK = rotátorköpeny

Berotáció

ROK-arthropathiás csoport

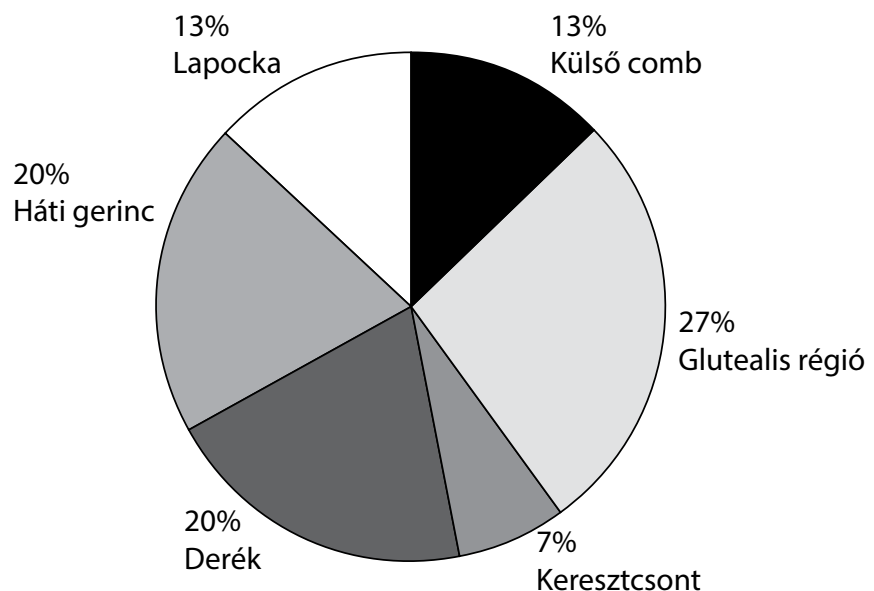

4. ábra

$\mid \begin{aligned} & \text { A két csoport berotációs mozgástartományának összehasonlítása } \\ & \text { ROK = rotátorköpeny }\end{aligned}$
Berotáció

Tumoros csoport

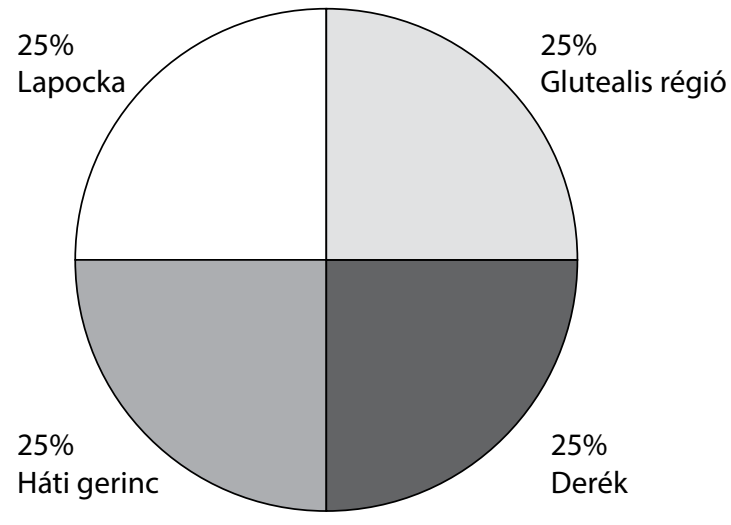

Ezzel szemben az aktív berotáció szignifikánsan szabadabb volt a tumoros betegeknél (4. ábra).

A posztoperatív röntgenfelvételeket ellenőrizve, lazulásra utaló jelet - protézis körüli radiolucens zónát, illetve osteolysist - egyik csoport betegeinél sem észleltünk. A rosszindulatú daganat miatt operált betegeknél - értelemszerúen az elváltozástól az onkológiai elveknek megfelelő biztonságos távolságban - az ép szövetekben történt a humerus reszekciója, közülük 6 betegnél homológ csontgraft, l betegnél pedig az ízület stabilitását javító Trevira hálóval is kiegészítettük a protézis beültetését. Ezeknél a betegeknél a csontgraft határánál, l beteg kivételével, jó csontos átépülést láttunk (5. ábra). A graft részleges felszívódása nem befolyásolta a stabilitást és az elérhető funkciót.

A vizsgálatot megelőzően azt feltételeztük, hogy a tuberositas deltoidea, vagyis a deltaizom tapadásának megkímélése kedvezően befolyásolhatja a későbbi vállízületi mozgásokat. A vizsgálati eredmények azonban nem erősítették meg ezt a feltételezést, sőt a tuberositas deltoidea szintje alatt végzett reszekciók esetén magasabb funkcionális pontértékeket tapasztaltunk (6. ábra). Figyelembe kell venni azonban, hogy mindössze két embernek reszekáltuk a felkarját a tapadás felett, ezért mintáink a kevés esetszám miatt sem alkalmasak messzemenő következtetések levonására. Egyik tumoros betegnél sem 


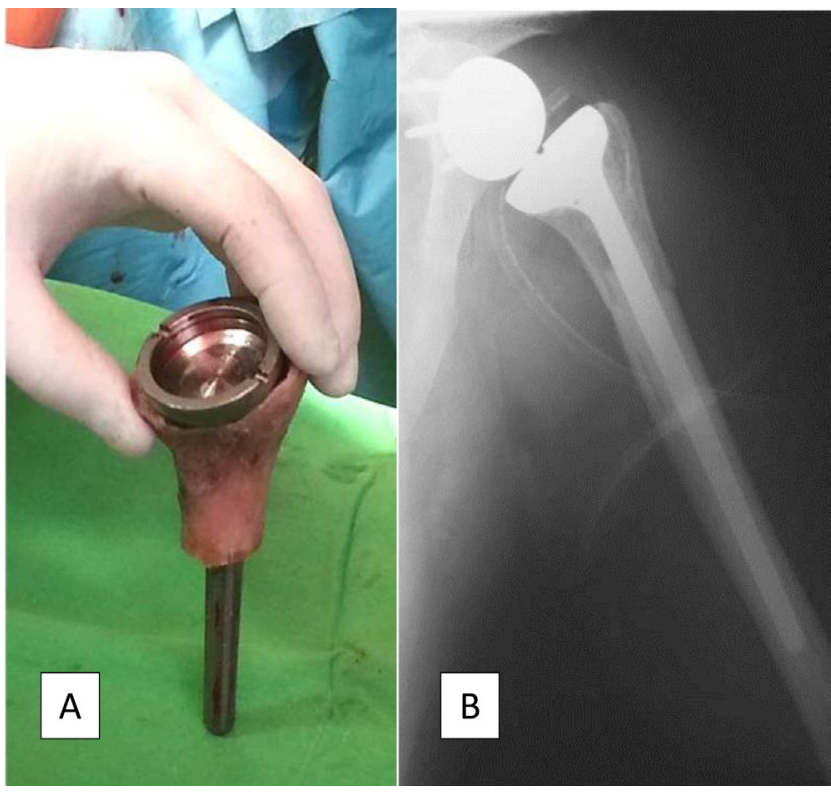

5. ábra

A) Intraoperatív kép. Allograft és deltaprotézis revíziós hosszú szárral (kompozit). B) Posztoperatív röntgen

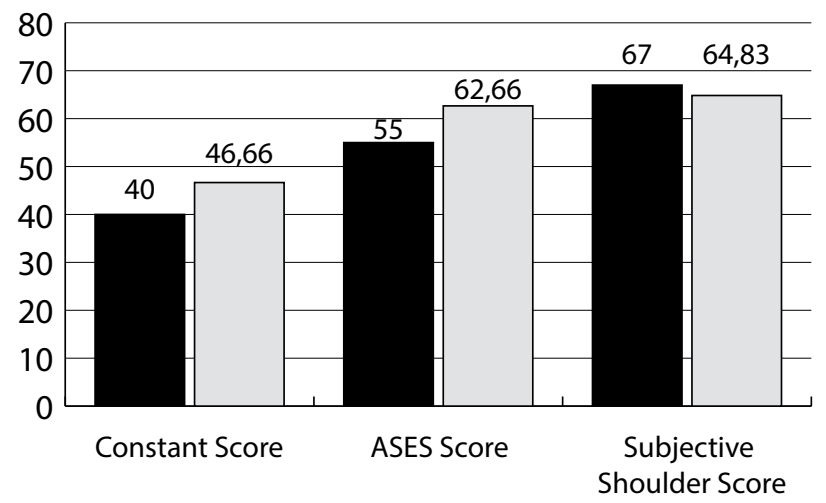

Tuberositas deltoidea felett

Tuberositas deltoidea alatt

6. ábra

| A humerusreszekció szintje szerinti összefüggések

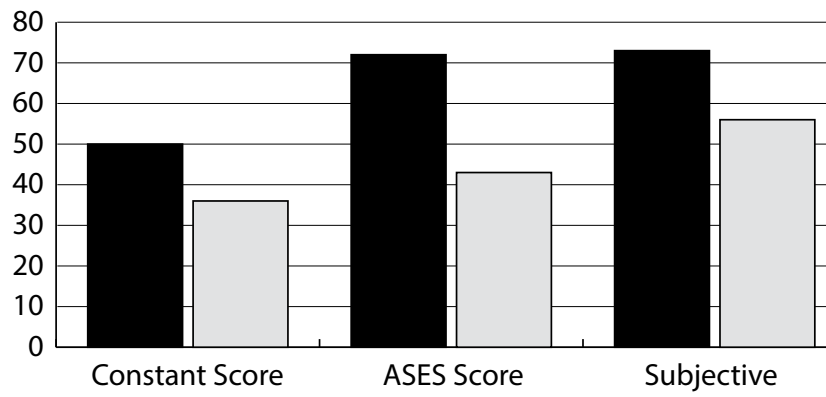

Volt luxatio

Nem volt luxatio

7. ábra | A luxatio és a funkcionális pontértékek közötti összefüggés volt érintett a glenoid, így reszekciót kizárólag a humeruson végeztünk.

A radikális reszekciókat követően az arthropathiás csoport eseménytelen posztoperatív időszakához képest a daganatos csoportban szereplő 8 betegből 5-nél észleltük 1 hónapon belül a protézis ficamát mint korai szövődményt. Az 5 betegből 2-nél ez konzervatívan kezelhető volt a vállízület repozíciójával, majd rögzítésével. A másik 3 betegnél a konzervatív kezelés után a protézis újból ficamodott. Ezeknél a betegeknél a stabilitást csak ismételt mütéttel tudtuk elérni. Azonban a későbbi funkcionális pontértékekre a luxatio mint szövődmény nem volt hatással (7. ábra).

\section{Megbeszélés}

A fejlett adjuváns kemoterápia, a sebészi technika és az endoprotetika fejlődése lehetővé tette a malignus csonttumorok kezelésében a végtagmegtartó mütétek térhódítását. Noha többféle módszer is ismert és használatos a humerus proximalis vég reszekcióját követő rekonstrukcióra, szakmai konszenzus mindeddig nem született az optimális módszert illetően. Munkánkban a reverz vállprotézis és homológ csontgraft kompozit beültetését vizsgáltuk mint lehetséges rekonstrukciós lehetőséget, és hasonlítottuk össze rotátorköpeny-arthropathia miatt beültetett reverz vállprotézisek funkcionális eredményeivel.

Bonnevialle és mtsai 8 csonttumor miatt reverz vállprotézis és homológ csontgraft kompozit beültetésén átesett beteget vizsgáltak, átlagosan 42 hónappal a beavatkozást követően. Ezen betegeknek átlagosan a Constant Score 52, a Subjective Shoulder Score 58 volt, a mi adatainkhoz hasonlóan, ahol a tumoros betegcsoportnál a Constant Score 45, a Subjective Shoulder Score 65 volt. Bonnevialle vizsgálatában az elevatio átlagos értéke 122 fok volt, a berotáció mérésekor a betegek az L4-es csigolya magasságát érték el az operált kezükkel. Ehhez hasonlóan a mi tanulmányunkban az elevatio átlagos értéke 110 fok volt, a berotáció során a betegek az Ll-Th12 magasságát érték el. Ellentétben a mi vizsgálatunkkal, ahol radiológiailag lazulásra utaló jelet, radiolucens zónát a protézis körül semelyik betegnél sem láttunk, Bonnevialle és mtsai 2 esetben is észleltek osteolysist a szár körül. Bonnevialle közleményében 2 alkalommal fordult elö luxatio, melyeknél mútéti úton lehetett tartós stabilitást elérni. A mi eseteinknél 5 alkalommal észleltünk luxatiót, 3 betegnél emiatt reoperáció is történt [8].

Egy 2013-ban megjelent dán közleményben 10 humerus proximalis vég reszekciót követően reverz vállprotézissel azonban homológ csontgraft beültetése nélkül operált beteget vizsgáltak átlagosan 46 hónappal a mútétet követően. Ezen betegek mozgástartománya - elevatio 98 fok, berotáció 51 fok - kissé elmaradt a mi betegeink mozgástartományához képest, ami a homológ csontpótlás kedvező hatása mellett szólhat [9].

Guven és mtsai 10 humerus proximalis vég reszekcióval operált beteget vizsgáltak, akiknél a rekonstrukció 
homológ csontpótlás nélküli reverz delta tumorprotézis beültetésével történt. Az utánkövetési idő 18 hónap, az átlagos reszekciós méret $10,2 \mathrm{~cm}$ volt. A mozgástartomány terjedelmében a mi eredményeinkhez képest elmaradtak, az elevatio 96 fok, az abductio 88 fok volt. Ellenben ók az eseteiknél nem említettek esetleges posztoperatív ficamot. Radiológiailag igazolt lazulást sem tapasztaltak, ami valószínúsíthetően a rövidebb utánkövetési idővel is magyarázható [10].

Teunis és mtsai 2014-ben publikált metaanalízisükben a legjobb eredményt adó humerus proximalis vég rekonstrukciós lehetôségét keresték. Átfogó vizsgálatukba 29 kutatás 693 betegét vonták be. A rekonstrukció módja szerint 3 csoportot hoztak létre, reverz deltaprotézis, reverz deltaprotézis-allograft kompozit, valamint osteoarticularis allograft csoportot. A legjobb eredményeket mind a funkcionális pontértékek, mind a komplikációk, mind a hosszú távú túlélés tekintetében a reverz vállprotézis-allograft kompozit és a reverz vállprotézis csoport betegei adták. Ha csak osteoarticularis graft használatával történt a reszekált proximalis humerus vég pótlása, gyengébb funkcionális pontértéket és magasabb szövődményarányt tapasztaltak, ráadásul számítani lehet a graft törésére is, ami többnyire mútéti megoldást igényel [11].

A reverz vállprotézis akár önmagában, akár csontallografttal kombinálva a leginkább abban különbözik a válltumorsebészetben eddig alkalmazott eljárásoktól, hogy ez a protézis már nemcsak passzív térkitöltőként szerepel, hanem a mindennapi életben is jól kihasználható aktív mozgásterjedelmet biztosít.

\section{Következtetés}

A vállízület reverz arthroplasticája évtizedek óta bevált módszer főként az idősebb, 65 év feletti, rotátorköpenyarthropathiás betegek gyógyításában. Kevés azonban a tapasztalat ezzel az eljárással az onkológiai indikáció alapján végzett végtagmegtartó mútéteknél, ahol a rotátorköpenyinak hiánya a tumoros humerusfej reszekciója folytán keletkezik. Vizsgált betegcsoportjainknál a tumoros betegek eredményei nem érik el ugyan a degeneratív arthropathia indikációjával operált betegekéit, láthatóan azonban megközelítik azt. Biztató eredményeink alapján úgy ítéljük, hogy érdemes a reverz vállprotézis beültetését mérlegelni daganatos betegség miatt humerus proximalis vég reszekciót követően a betegek vállának és felkarjának rekonstrukciójára. Mivel jelenleg középtávú eredményeink alapján nyilatkozunk, az onkológiai indikációval beültetett protézisek várható élettartamáról egyelőre nem állnak rendelkezésünkre adatok. Jelenlegi tapasztalataink alapján azt mondhatjuk, hogy a reverz protézis végtagmegtartó jelleggel végzett beültetése már fiatal felnőtt kortól végezhető, a betegek fizikai aktivitását figyelembe vevő és mindennapi életvitelüket messzemenően megkönnyítő eljárás.

Anyagi támogatás: A közleménnyel kapcsolatos kutatómunka anyagi támogatásban nem részesült.

Szerzői munkamegosztás: Sz. A.: Adatgyưjtés, betegvizsgálat, röntgenfelvételek kiértékelése, a kézirat megírása. B. B.: Adatgyüjtés, a betegekkel való szóbeli konzultáció. P. T., Sz. K., S. G.: Adatgyưjtés és betegvizsgálat. S. I.: Adatgyüjtés, röntgenfelvételek kiértékelése. Sz. M.: A kézirat szakmai lektorálása. A. I.: Operációk végzése, a kutatás koordinálása, a szöveg szakmai lektorálása. A cikk végleges változatát valamennyi szerző elolvasta és jóváhagyta.

Érdekeltségek: A szerzőknek nincsenek érdekeltségeik.

\section{Irodalom}

[1] Singh JA. Epidemiology of knee and hip arthroplasty: a systematic review. Open Orthop J. 2011; 5: 80-85.

[2] Schairer WW, Nwachukwu BU, Lyman S, et al. National utilization of reverse total shoulder arthroplasty in the United States. J Shoulder Elbow Surg. 2015; 24: 91-97.

[3] Hyun YS, Huri G, Garbis NG, et al. Uncommon indications for reverse total shoulder arthroplasty. Clin Orthop Surg. 2013; 5: 243-255.

[4] Kitagawa Y, Thai DM, Choong PF. Reconstructions of the shoulder following tumour resection. J Orthop Surg. 2007; 15: 201-206.

[5] Rödl RW, Gosheger G, Gebert C, et al. Reconstruction of the proximal humerus after wide resection of tumours. J Bone Joint Surg Br. 2002; 84: 1004-1008.

[6] Kumar D, Grimer RJ, Abudu A, et al. Endoprosthetic replacement of the proximal humerus. Long-term results. J Bone Joint Surg Br. 2003; 85: 717-722.

[7] Fuhrmann RA, Roth A, Venbrocks RA. Salvage of the upper extremity in cases of tumorous destruction of the proximal humerus. J Cancer Res Clin Oncol. 2000; 126: 337-344.

[8] Bonnevialle N, Mansat P, Lebon J, et al. Reverse shoulder arthroplasty for malignant tumors of proximal humerus. J Shoulder Elbow Surg. 2015; 24: 36-44.

[9] Kaa AK, Jørgensen PH, Søjbjerg JO, et al. Reverse shoulder replacement after resection of the proximal humerus for bone tumours. Bone Joint J. 2013; 95: 1551-1555.

[10] Guven MF, Aslan L, Botanlioglu H, et al. Functional outcome of reverse shoulder tumor prosthesis in the treatment of proximal humerus tumors. J Shoulder Elbow Surg. 2016; 25: el-e6.

[11] Teunis T, Nota SP, Hornicek FJ, et al. Outcome after reconstruction of the proximal humerus for tumor resection: a systematic review. Clin Orthop Relat Res. 2014; 472: 2245-2253.

(Szatmári Attila dr., Budapest, Üllői út 78/B, 1082 e-mail: szattilal113@gmail.com) feltéve, hogy az eredeti szerző és a közlés helye, illetve a CC License linkje és az esetlegesen végrehajtott módosítások feltüntetésre kerülnek. 